\section{Legacy of the scientific collections of the Instituto de Investigação Científica Tropical, University of Lisbon: a critical review and outlook}

\section{Legado das coleções científicas do Instituto de Investigação Científica Tropical, Universidade de Lisboa: uma revisão crítica e perspetivas}

\author{
CONCEIÇÃO \\ CASANOVA ${ }^{1,2,3 *}$ (i) \\ MARIA M. ROMEIRAS $4,5,6$ (i) \\ 1. Departamento de Conservação \\ e Restauro, FCT, Universidade \\ NOVA de Lisboa, Portugal \\ 2. LAQV- Requimte - Laboratório \\ Associado para a Química Verde, \\ FCT, Universidade NOVA de \\ Lisboa, Portugal \\ 3. Instituto de Estudos Medievais, \\ FCSH, Universidade NOVA de \\ Lisboa, Portugal \\ 4. Linking Landscape, \\ Environment, Agriculture and \\ Food (LEAF), Instituto Superior \\ de Agronomia (ISA), Universidade \\ de Lisboa, Portugal \\ 5. Centre for Ecology, Evolution \\ and Environmental Changes \\ (cE3c), Faculdade de Ciências, \\ Universidade de Lisboa, Portugal \\ 6. Academia das Ciências de \\ Lisboa, Portugal \\ *mccasanova@fct.unl.pt
}

\section{KEYWORDS}

Historic and scientific collections

Preventive conservation IICT

Portuguese-speaking countries

\section{PALAVRAS-CHAVE}

Coleções históricas

e científicas

Conservação preventiva IICT

Países de Língua

Portuguesa 


\section{Introduction}

\section{Background}

The historical and scientific collections here presented are currently at the University of Lisbon, as a result of the integration in 2015 of the Instituto de Investigação Científica Tropical (IICT, Tropical Research Institute) in the largest Portuguese university, the University of Lisbon (UL) [1]. Most of the scientific collections are now under the management of Museu Nacional de História Natural e da Ciência (MUHNAC, National Museum of Natural History and Science). Nevertheless, the archaeological collection was placed on a long-term loan at the Faculdade de Letras da Universidade de Lisboa (FLUL, Faculty of Humanities, UL), where most of the libraries were integrated. Additionally, the huge living coffee collections of the Centro de Investigação das Ferrugens do Cafeeiro (CIFC, Coffee Rust Research Centre), the main xylotheque (wood collection) and the earth science collections are under the management of the Instituto Superior de Agronomia (ISA, School of Agronomy, UL). On the other hand, the collections of the Arquivo Histórico Ultramarino (AHU, Overseas Historical Archive), were no longer integrated in the UL, but in DirecçãoGeral do Livro, dos Arquivos e das Bibliotecas (DGLAB, General Directorate of the Book, Archives and Libraries), under the Ministry of Culture.

The history of IICT goes back to the Comissão de Cartografia (CC, Cartography Commission) established 19 April 1883, by José Vicente Barbosa du Bocage (1823-1907), then overseas and foreign affairs minister. The creation of CC, partly motivated by the so-called "scramble for Africa" [2], included what were initially designated geographic and cartographic expeditions and later scientific expeditions or missions. These aimed at advancing the "scientific exploration of the colonies" [3], in line with the directives of the 188485 Berlin Conference, also known as the Congo Conference, where the borders of European colonies in Africa were established. The potential and value of the regions already occupied by Portugal remained, until then, largely unknown.

The IICT scientific heritage is thus the result of scientific research and praxis developed over 132 years in the countries of the present Community of Portuguese-Speaking Countries (CPLP): Angola, Brazil, Cabo Verde, East Timor, GuineaBissau, Mozambique, Portugal, and São Tomé e Príncipe. This unique heritage of unequivocal interest bears testimony to the knowledge rooted into the natural and cultural diversity of the Tropics and can be seen as IICT's identity mark, for its singularity, symbolism and value as a whole.

When considering the historical and scientific collections altogether, including libraries and archives, the total number of items can be estimated at more than one and a half million. To these figures contribute the bibliographic catalogue, including the Centro de Documentação e Informação (CDI, Information and Documentation Centre) and publications edited by the IICT, including up to ca. 94,000 monographic works, ca. 13,000 titles of scientific journals, ca. 8,000 cartographic documents, a unique photography collection of more than 260,100 items dating from 1860 to 1974, and 543 film records from 1932 to 1983 . Moreover, the central archives of IICT hold roughly $2.5 \mathrm{~km}$ of documents: $1 \mathrm{~km}$ corresponding to administrative archives and the remaining $1.5 \mathrm{~km}$ corresponding to archives of the different research units, encompassing field notebooks, technical scientific reports and other unpublished records. The relevance of these documents is paramount to the history of science and other natural sciences studies as the collections enable data comparison through time and the analysis of developments in tropical regions in different fields of knowledge. Closely related to the IICT bibliographic and archival collections are the collections of the AHU, created in 1931, within the Ministry of Colonies. This archive, transferred to the IICT in 1973 (and integrated in DGLAB in 2015), holds more than 15 $\mathrm{km}$ of records produced by the Portuguese overseas offices, between the mid-17th century and 1974 [4-5].

If we exclude archives and libraries, the IICT collections are estimated at about half a million items. The anthropological, ethnographic and archaeological collections, mostly collected between 1930-1980, include ca. 136,979 archaeological artefacts, 421 ethnoarchaeological items, 868 ethnographic artefacts and 16,000 blood samples. The natural history collections encompass: 1) botanical collections (ca. 300,000 herbarium specimens, ca. 1,700 fluid-preserved specimens, plus two xylotheques (wood collections) with ca. 8,000 samples of different species); and 2) zoological collections (ca. 82,000 specimens, including ca. 70,000 arthropods, and smaller collections, such as the fluid-preserved collection of reptiles and amphibians, the mammal collection and the bird collection). The earth sciences collections comprise 29,261 soil samples, 60 monoliths, 2,219 mineral and geologic samples, plus hundreds of mounted slides resulting from research. The Jardim Botânico Tropical (JBT, Tropical Botanical Garden) includes ca. 1,000 living plants and the Index Seminum (i.e., seed collection). The CIFC holds a collection of ca. 8,500 plants, derived from ca. 2,700 genotypes of Coffea spp. with diverse geographical origin and interspecific hybrids, plus a comprehensive pathogenic fungi germplasm bank (several isolates of Hemileia vastatrix and of Colletotrichum kahawae).

The scientific instruments collection (ca. 200 items) is also an important part of IICT heritage, as evidence of the practices of science in the 2oth century and thus fundamental to the history of science and technology. Finally, the core collection of the Museu Nacional de Etnologia (MNE, National Museum of Ethnology) should also be mentioned because of its close relation to IICT collections. Founded in 1965 in the IICT's institutional sphere as the Museu de Etnologia Ultramarino (MEU, Overseas Ethnology Museum), the MNE become an autonomous institution in 1989.

Although distinct, these collections share collecting purposes and geographical scope, as well as relevance as a tropical research infrastructure and an instrument of cooperation and development between Portugal and the other 
Portuguese-speaking countries. The collections respond to the challenges and demands of present-day society, having: 1) a relevant social and cultural value, and bear testimony to the relations between Europe and the African continent; and 2) a strong economic and political value, being an essential instrument for the responsible management of natural resources, within the framework of sustainable development policies.

\section{Institutional developments}

As mentioned above, the first institution responsible for the scientific and historic collections was the Cartography Commission (Figure 1). From the very beginning, the Commission's approach was interdisciplinary, comprising different fields of knowledge, namely the social sciences under "political geography" and the natural sciences under "physical geography" [4]. The CC created a library, which included both the state of the art of extant colonial cartography at the time, in addition to the cartography produced by the Commission itself. An important outcome was the Charter of Southern Portuguese Africa. This roughly corresponded to the "pink map" [6], drawn after the first scientific missions for border delimitation (geographic and hydrographic missions).

The CC underwent several structural changes and different designations throughout its history [5]. It was followed by the Junta de Missões Geográficas e de Investigações Coloniais (JMGIC, Colonial Research and Geographic Missions Board), with Decree no. 26 180, 7 January 1936. According to the legislator, apart from the need to continue border delimitation work, the new institution was expected to broaden its research scope. It was also expected to preserve the scientific materials collected during the missions, then extended to botany, zoology, geology, ethnography, anthropology and archaeology, as well as health and environmental studies [7].

Under Decree no. 35 395, 26 December 1945, the JMGIC became the Junta de Investigações Coloniais (JIC, Colonial Research Board) and was considerably reformed in the direction of increased decentralisation and expansion. No limits were imposed on the number of collaborators, aiming "to study and academically discuss the colonial scientific problems" [8]. The JIC welcomed several partners and established close working relations with national universities and research centres settled in the colonies. As Castelo [9] noted, by bringing together members of various universities and experts in diverse fields of knowledge, the JIC took advantage of the national university system critical mass and significantly increased its access to the colonial field. As a result, the institution became a powerful scientific instrument and the largest national and colonial network. During this period, the Colonial Scientific Documentation Service (later CDI, located in the last years at the Calheta Palace, Belém) and the Scientific and Campaign Equipment Storage (which some of the heritage was later found at the former Zoology Centre, Junqueira) were created. Furthermore, in 1948, the Herbarium (Herbário, LISC) was established [4]. The LISC, kept at specific facilities created in the former Botanic Centre, Palácio Burnay / Junqueira, in the beginnig of 2020 was transferred to MUHNAC to recently upgraded facilities, shared with the Herbarium (Herbário, LISU) of University of Lisbon.

After the 1951 constitutional revision (Law 2048 of 11 June 1951) and the Colonial Act (law establishing relationships between Portugal and its colonies), the term colonial was gradually replaced by the term ultramarino (overseas), in accordance with the new constitutional terminology [10, 11 art. $4^{\circ}$ ]. This change was a rather cosmetic one, since there was no intention to question the nation's pluricontinental unity [9]. Although it has not been yet possible to locate the legal document supporting the official change, the Junta de Investigações do Ultramar (JIU, Overseas Research Board) became the name frequently used in official documents and legislation during the 1960s. Among JIU's achievements with impact on scientific heritage, it is worth mentioning the creation/establishment, in 1965 [5], of the above mentioned MEU, under the direction of António Jorge Dias (1907-1973). Dias - a Portuguese ethnologist and cultural anthropologist, who led the Missões de Estudo das Minorias Étnicas do Ultramar Português (i.e., Missions for the Study of Ethnic Minorities of the Portuguese Overseas) - conceived the

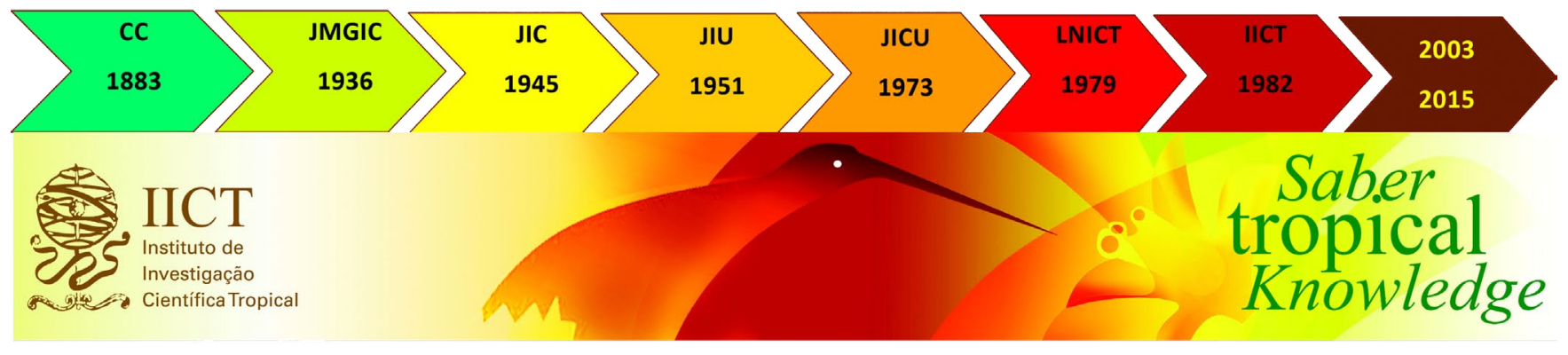

Figure 1. IICT 2015 Banner and evolution of the institutional acronyms (IICT, 2015). 
Museum as an important tool of dissemination of African culture. The exhibition "Vida e Arte do Povo Maconde" (Life and art of the Maconde people, authors translation), organised in 1959 mainly with objects collected during this mission became the basis for the Museum concept.

In 1973, another Decree no. 583/73 of November 6/1973 [12], led to yet another name change - the institution became the Junta de Investigações Científicas do Ultramar (JICU, Overseas Scientific Research Board) - and yet another reform, oriented towards centralization. The JICU became autonomous in administrative and financial terms and expanded its services under the Overseas Ministry, receiving jurisdiction over: 1) the Jardim e Museu Agrícola do Ultramar (JMAU, Overseas Agricultural Museum and Garden), today the JBT (after the former Jardim Colonial and Museu Agricola Colonial, both created in 1906 and the latter discontinued in 1992) [5]; 2) the above-mentioned AHU; and 3) the Centro de Estudos Históricos Ultramarinos (CEHU, Overseas Historical Studies Centre), created in 1955 and responsible for developing research into the history of portuguese presence overseas, which includes the Filmoteca Ultramarina Portuguesa (FUP, Portuguese Overseas Film Archive), created to assemble microfilms of records documenting that presence, comprising more than 500,000 images [4, 12].

These changes were abruptly interrupted by the new political and social framework resulting from the revolution of 25 April 1974, which reintroduced democracy in Portugal. Perhaps unsurprisingly, a general crisis in the Overseas Ministry was ultimately followed by extinction, leaving its different structures - such as JICU - in undefined status [5]. The institutional situation was only clarified in 1976, when JICU became part of the Ministry of Culture and Science. On 31 December 1979, Decree no. 532 replaced JICU by the Laboratório Nacional de Investigação Científica Tropical (LNICT, National Laboratory of Tropical Scientific Research), oriented towards the development of scientific cooperation policies with the CPLP countries [13]. This decree omitted the ethnology museum and its collections since the prevailing idea was to establish an independent structure: the InstitutoMuseu Nacional de Etnologia (i.e., National Institute-Museum of Ethnology) [14]. However, the idea was temporarily reverted when IICT was created on 8 April 1982, by the Decree no. $105 / 82$, which included a museological component $[6,15]$. In the aftermath of the reform carried out in 1982, 24 research centres covering the natural sciences, social sciences and humanities were created to develop scientific work in IICT [4-5]. Six years later, the Decree no. 249/89 dated 8 August 1989, moved IICT from the Ministry of Culture and Science to the Ministry of Management and Territorial Planning, ultimately resulting in the transition of the ethnology museum to the recently created MNE [16]. This became the first major dispersion of the IICT scientific and historical collections.

After two decades of stability, the last important reform of IICT resulted from Decree no. 297/2003 of 21 November 2003, which postulates the Normative Order no. 32/2005, when the institute internal regulation was defined [17-18]. A drastic simplification of the institutional structure was introduced, reducing the number of centres from 24 to 10 and the number of departments from six to two (i.e., Departamento de Ciências Naturais, DCN and Departamento de Ciências Humanas, DCH). Moreover, a Monitoring Unit composed of five specialists, two of which international, was created. The Orientation Council, comprising a maximum of 10 members, including representatives of different ministries, was also created. These structures were meant to advise and validate the Managing Unit, guaranteeing the internationalization of IICT and stimulating interdisciplinary approaches. On the other hand, increased relevance was given to IICT's scientific collections, now redirected towards a more central role in the internationalization effort and the cooperation context, a point we will detail later in this text. During this period, initiatives were made to recover, preserve and increase access to the collections, including those at the time outside the IICT but assembled during missions under the jurisdiction of Junta. These included, for example, the ethnographic collections collected by Mendes Correia (1888-1960), formerly housed at the University of Porto, and the Schiappa de Campos archives (1926-2018), a private collection donated to IICT in 2014, among others. Also, an effort was made to increased access to the MNE collections by IICT researchers through the establishment of a protocol with the Ministry of Culture in 5 July 2005.

The last reform aimed at mitigating the negative impact on IICT that resulted from its first international evaluation, promoted in 1997 by the Ministry of Science and Technology, within the framework of the state laboratories evaluation [6, 14]. This evaluation recommended the dismantlement of IICT into three distinct structures, ultimately separating heritage from research and researchers, in line with the previously mentioned decision to separate the ethnology heritage.

Ultimately, a similar separation happened a dozen years later, when IICT was integrated in the University of Lisbon and in the DGLAB at the Ministry of Culture. As mentioned before, responsibilities for the preservation, management and access to IICT scientific collections and archives were mostly attributed to the MUHNAC, while the central archive of IICT was attributed to the central services of the University of Lisbon. On the other hand, research staff was mainly integrated in the FLUL (namely researchers from the former DCH) and in the ISA (namely researchers from the former DCN).

\section{Scientific and Historical Collections Management Strategy (2005-2015)}

From the early days of the 2003 reform, the new IICT management team aimed to promote interdisciplinary research of the scientific and historical collections, which were understood as the identity mark of IICT. The mission statement and strategic management was based on two main priorities: 1) measuring and improving the quality and relevance of tropical 
research, particularly through the programme Millennium Development Goals (United Nations joint effort to meet the needs of the World's poorest) in Portuguese-speaking countries; and 2) evaluating and preserving scientific heritage in accordance with the Portuguese Initiative [5], an agreement resulting from the II meeting of CPLP Ministers of Science and Technology, in 2003, in Rio de Janeiro. The latter corresponded to the commitment by the Portuguese government of making accessible IICT's scientific and cultural heritage to all CPLP countries. The CPLP ministers aimed to develop exchanges among CPLP members' museums, archives and scientific institutions and support the Portuguese Initiative of making IICT's collections available to other CPLP countries [19]. The final statement was unanimously signed by all ministers, including the Portuguese minister of science and higher education (Maria da Graça Carvalho). Endowed by this strong diplomatic and cooperative duty, conditions for the systematic treatment and increased access to IICT's collections were facilitated and a dedicated and innovative programme was established. This programme, which was underway for 10 years, until IICT joined the University of Lisbon, acted as a platform to share and disseminate knowledge related to the tropics. It encompassed activities of conservation, digitization, research, capacity building and cooperation around scientific and historical collections, favouring partnerships with local research entities and universities in Portuguese-speaking countries.

The programme also supported training in these countries as a core principle of the cooperation agreements. Thus, the initiative contributed to improve tropical research and increase our knowledge of the culture and history of tropical countries, notably those where Portuguese is the official language. The programme was supported by the Fundação para a Ciência e Tecnlogia (FCT, Portuguese Foundation for Science and Technology) through the provision of grants and post-doc fellowships, through the Programa do Compromisso com a Ciência (i.e., Science Compromise Programme). A total of 15 research grantees and three post-docs were hired to meet the Programme's objectives. Later, the work of these researchers was also fundamental to support the transfer of collections to the University of Lisbon.

The whole process involved three main steps:1) since 2005 , the implementation of the Programa Interministerial de Tratamento e Valorização do Património do IICT (PI, Interministerial programme for the treatment and valorisation of IICT heritage), which involved the survey and preservation of collections through the establishment of a collection care policy; 2) in 2007, under the framework of the reform of State Laboratories established by the 124/2006 resolution of the council of ministers, the creation of the project Arquivo Científico Tropical (ACT, Tropical Scientific Archive), which involved promoting study and access to IICT collections through the development of the online platform Arquivo Científico Tropical Digital (ACTD, Digital Tropical Scientific Archive); and finally 3) in 2011, in the International Year of Forests, the launch of the project Promoção do Saber Tropical (PST, Promoting Tropical Knowledge), concerning mainly tropical ecosystems conservation, based on IICT vast biological heritage (botanical and zoological collections). These three steps are discussed in detail below.

\section{Step 1: Survey and preservation}

As far as collections' care is concerned, initial priority was given to locate and identify IICT's diverse and dispersed heritage. The task was challenging due to the sequence of institutional reforms and IICT's geographic dispersion. In 2003, the Institute had 24 different addresses in the city of Lisbon, Oeiras and Coimbra. A significantly heterogeneous situation was found, from considerably accessible and curated collections such as the LISC Herbarium and the AHU, to the lack of curatorial staff in other research centres for collections care, which became increasingly acute, mostly due to staff ageing. This situation inevitably led to risk of damage and loss due to inappropriate storage or lack of preservation facilities. Given this scenario, the principal task was to set up a systematic survey to identify and characterise the different collections (Figure 2). An inquiry was sent to researchers in charge, followed by regular visits by small teams, which always included a conservator-restorer, a specialist/curator and a collections manager. Characterisation included the collection's dimension/volume, their storage and conservation condition, their use (e.g., research, exhibition, others), regular care procedures and the level of treatment required. The existence of associated documentation was considered critical as it enables proper inventory and heritage significance recognition, thus was also registered in the survey.

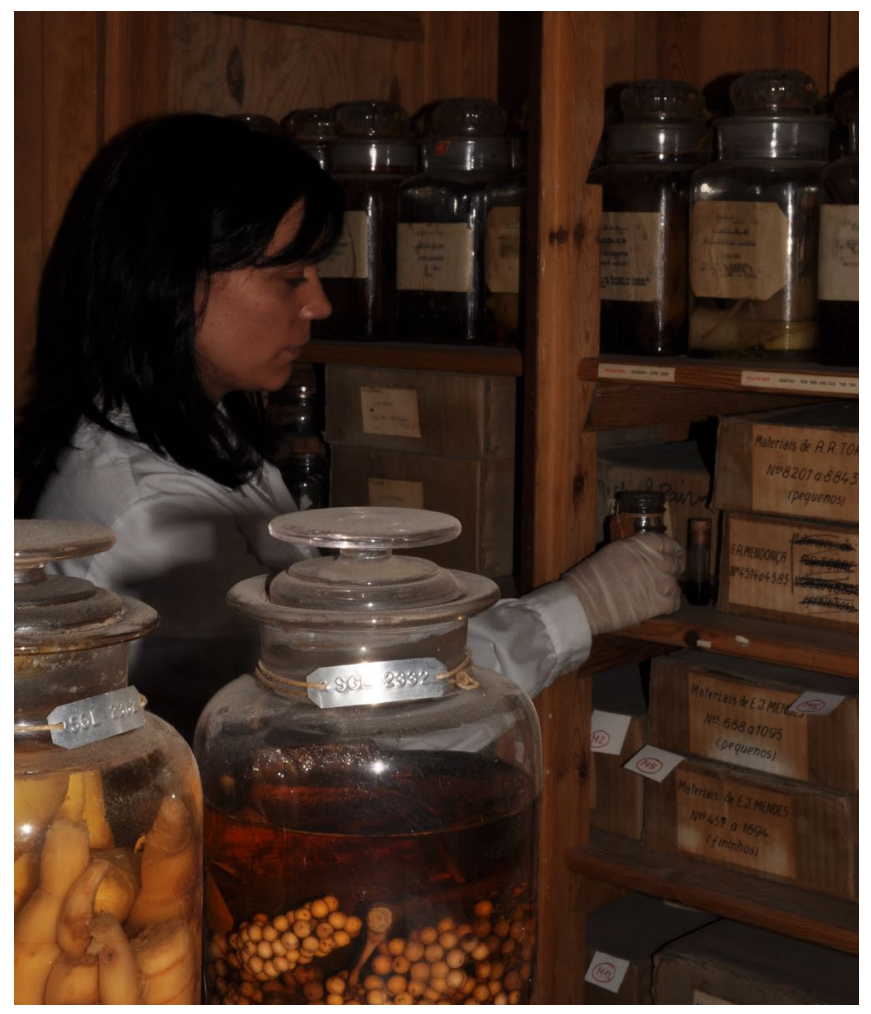

Figure 2. Botanical collections survey (IICT, 2013). 
The survey showed that more than $45 \%$ of the heritage was at risk due to inappropriate storage conditions and poor conservation condition. Moreover, ca. $39 \%$ of the scientific collections had insufficient associated documentation available and for $6 \%$ no associated documentation at all was found. Digital treatment comprised only $17 \%$ of all IICT collections.

The second task concerned the implementation of preventive conservation procedures for the different collections and establishing a preservation policy - the first ever - for IICT [5, 20].

Despite the large number of collections under its care, IICT did not offer standard conservation requirements for some collections. The building that raised the greatest concern was the one hosting the zoology collections. Hence, it was proposed to the minister of science and technology - Mariano Gago (1948-2015) - the construction of a new building in the land adjacent to the old one, with adequate storage facilities. Unfortunately, the economic crisis which profoundly impacted Portugal after 2008 precluded this initiative.

Usually, the main factors that affect long-term preservation of historical and scientific collections are light, temperature, relative humidity and pests. Thus, the implementation of a preventive conservation policy at IICT included regular monitoring of temperature, humidity and light in storage areas, coupled with the establishment of an integrated pest management program (IPM). Objects in storage were periodically inspected for evidence of insect activity (e.g., eggs, larvae, new powdery deposits or small holes), as well as mould evidence. This allowed early detection of infestations and further damage. Contaminated objects or collections were placed in isolation and treated under anoxic conditions. Basic conservation procedures were also implemented, such as regular dry cleaning (Figure 3) and proper storage conditions, taking into account collections' particular needs, such as low temperature requirements (Figure 4). Methods for secure display and storage, as well as staff training to ensure the integrity of objects during handling, transport and loans between IICT departments or to external institutions, were also main concerns. Other important improvements included the establishment of adequate procedures for object handling

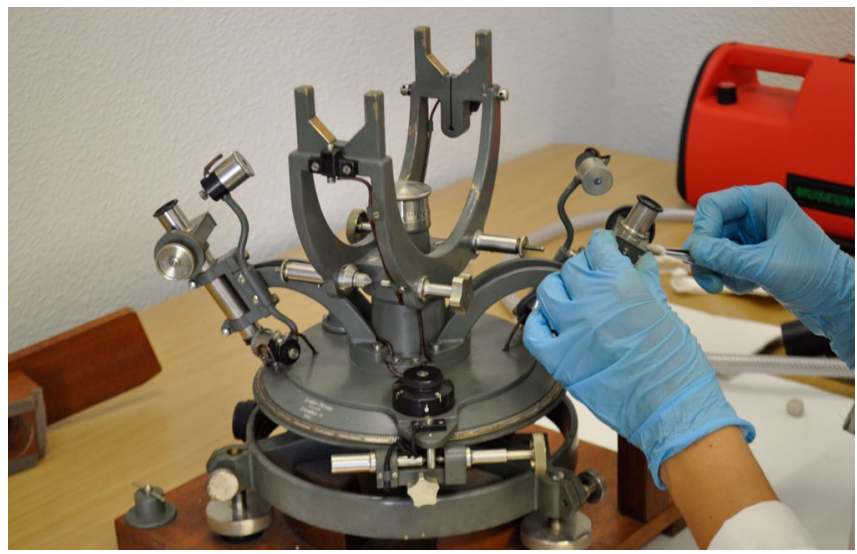

Figure 3. Cleaning operation of scientific equipment (IICT, AHU, 2010). in collections regularly being used for teaching activities and located outside IICT facilities (e.g., ISA).

\section{Step 2: Study \& access}

In 2006, the importance of the Portuguese Initiative was emphasised and supported by UNESCO. Joie Springer, a member of the information society division and the universal section Access and Preservation of UNESCO, visited the IICT. Springer considered that IICT should increase access and dissemination of heritage, which she considered of the highest relevance for humanity. Apart from the study, treatment and digitization, Springer suggested an application to the UNESCO program Memory of the World Register in order to seek recognition of the outstanding universal value of some of the IICT documental collections. Increasing access to IICT heritage included collections study, identification and classification, as well as their online accessibility. Individual databases with digital inventories did exist, but they brought little added value to the heritage as a whole, representing, as mentioned early, only $17 \%$ of the total collections. Thus, expansion of the digital inventory scope was an early objective. For the Herbarium, the BRAHMS database, a natural history database developed by the University of Oxford to manage the collection, already adopted by IICT researchers, was kept in use. In parallel, SPECIFY, an open access software common with biological collections, was adopted for the zoology collections; and the software MATRIZ - Museum Collections Inventory and Management, used by national museums in Portugal, was adopted for the ethnographic and archaeological collections.

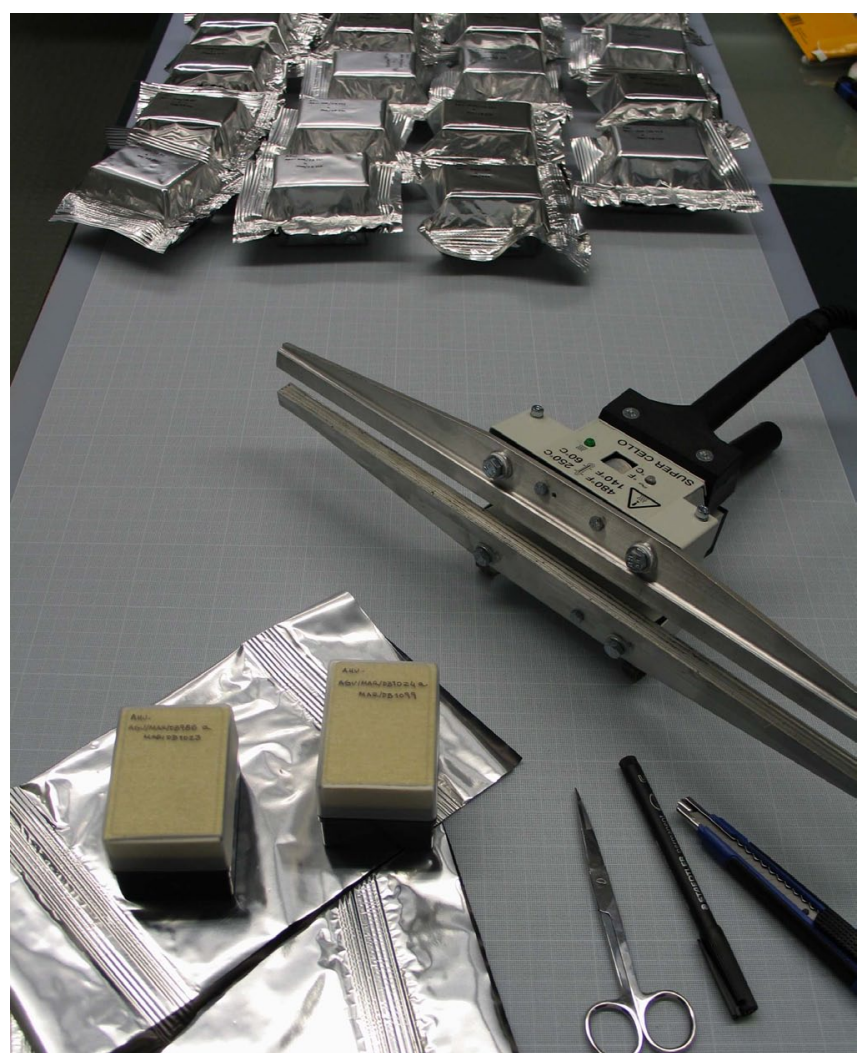

Figure 4. Packaging for cold storage (IICT, AHU, 2006). 


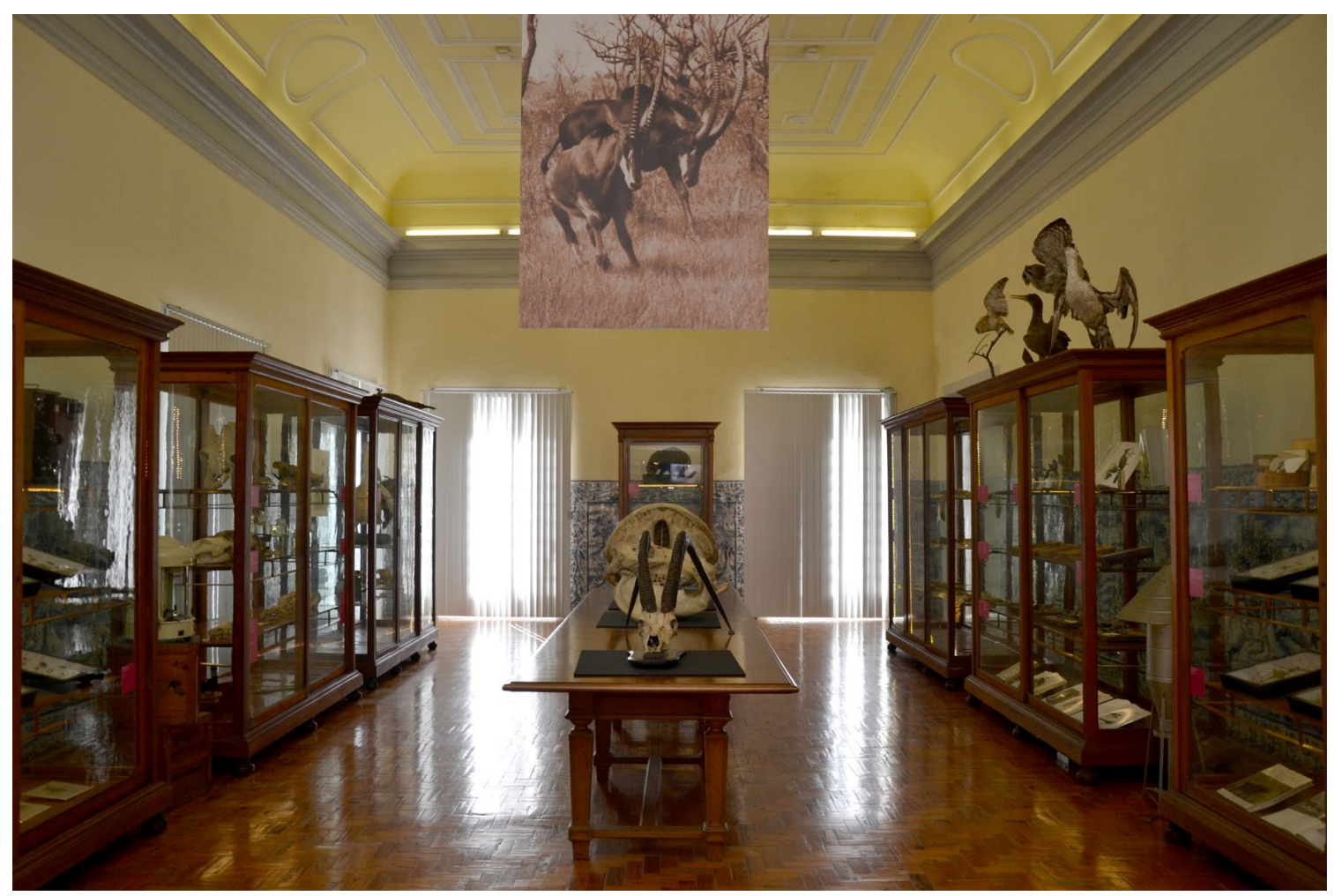

Figure 5. Exhibition “Viagens e Missões Científicas nos Trópicos 1883-2010” (IICT, Calheta Palace, 2010).

In 2007-2008, a second main step was to provide access to IICT collections and archives through a single online platform. ACTD, an institutional repository based on open source software, was created, bringing together primary information from several databases and enabling users from all over the world to conduct autonomous searches based on the item type, scientific domain/topic and geography. This online platform aimed to collect, preserve, manage and disseminate both IICT's collections and research outreach, thus encouraging innovation in tropical scientific research.

During this step, an oral history programme was also developed to collect testimonies and life stories of IICT researchers and technicians and to make them available through ACTD. Moreover, a research line on the history of science was initiated, leading to the exhibition "Viagens e Missões Científicas nos Trópicos, 1883-2010" (Scientific Travels and Missions in the Tropics, authors' translation) (Figure 5). This exhibition, promoted by IICT under the auspices of the centenary of the republic national celebrations [21], provided access of IICT's scientific heritage and collections to broad segments of the public. These two initiatives where supported by a consortium composed of IICT, the Centro de História e Filosofia da Ciência e da Tecnologia of NOVA University of Lisbon (i.e., History and Philosophy Centre of Science and Technology; nowadays Centro Interuniversitário de História das Ciências e da Tecnologia, after the merge with the Centro de História das Ciências da Universidade de Lisboa) and ALGORITM Centre of the University of Minho.

In short, at this stage, several investments made in the study and dissemination of the collections for the benefit of the scientific community and the general public, through the treatment, publication, exhibition and, particularly, online access, by specialized databases and the digital repository ACTD, resulted in the consolidation of IICT's scientific collections and heritage as a strategic vehicle for international cooperation.

\section{Step 3: Policy consolidation}

Established in the last phase of IICT, the PST project was anchored on an agreement contract by IICT and FCT to ensure a considerable number of grants (i.e., 18) to continue the study and treatment of the IICT scientific collections. These grants would later be transferred to the University of Lisbon. Other agreements signed to improve collections standards and access included: 1) a collaboration with the Arquivo Nacional da Imagem em Movimento (ANIM, Nacional Archive of Movement Image) for film conservation and long term loan; 2) an agreement with Laboratório Nacional de Energia e Geologia (LNEG, National Laboratory of Energy and Geology) for mineralogical and geological collections preservation at the LNEG lithotech in Alfragide (near Lisbon); and 3) several agreements with researchers for long term loan or transfer of archival material and photographs, such as the abovementioned collection of native habitat studies mission of Guinea-Bissau (1959-1960) from architect Fernando Schiappa Campos, and the collections resulting from several botanical expeditions by the botanist José Mendes Ferrão.

During this third step, the main access policy [22] and the loan rules [23] were revised and established, according to museum standards. Main assessment criteria included: object availability and value, conservation condition and size and relevance of the request in relation to IICT priorities. 
Moreover, loan approvals were based on travel and display adequacy of the object(s), as well as the capacity of the borrowing institution to meet security requirements and care standards.

Another important preservation initiative was the creation of an open storage for the ethnographic collections in Calheta Palace (Figure 6). The open storage, comprising four rooms, was visited by appointment by researchers, school groups and senior groups, for investigation and education proposes or simply to enjoy the experience of visiting the collections. This storage facility also worked as a communication tool, namely addressing the minorities from the CPLP communities in Portugal, which were particularly invited to participate in special events such the international museums day and the European researchers' night, among others.

The improvement of data quality and access under PST included: 1) collections' georeferencing in ACTD; and 2) protocols for integrating ACTD data into the Registo National de Objectos Digitais (RNOD, Digital Objects National Record), thus becoming also accessible through EUROPEANA. Moreover, in 2013, FCT designated IICT as the Portuguese node of GBIF (i.e., Global Biodiversity Information Facility), an initiative aiming at bringing online access to biodiversity data.

The last two decades have been shaped by the effort to make IICT scientific data available to global networks and the need to create worldwide information platforms accessible to all researchers (e.g., GBIF; EUROPEANA Collections). A significant corpus of scientific research has resulted from these efforts, as detailed in the next section.

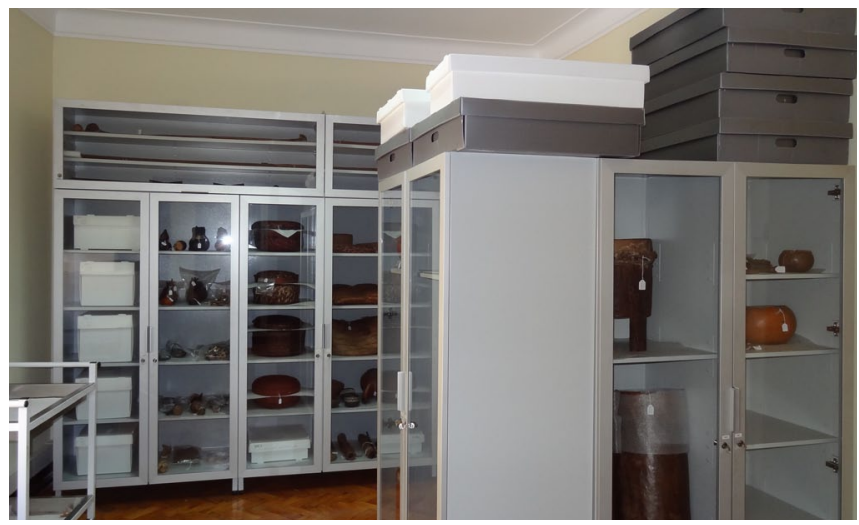

Figure 6. Open Storage Room (IICT, Calheta Palace, 2012).

\section{Main achievements}

\section{Outputs}

The multidisciplinary and diversity of the research lines developed under the Portuguese Initiative - comprising the PI programme, the ACTD and the PST - contributed to the acquisition and accessibility to a wealth of knowledge. They have also strengthened the role of Portugal as a key collaborative player alongside other international institutions with important collections from CPLP countries.

Information from biological collections, coupled with the legacy of several twenty century seminal studies by renowned naturalists, such as John Gossweiler (1873-1952) and Luís Augusto Grandvaux Barbosa (1914-1983), who published the Phytogeographical map of Angola, are still the baseline for more recent studies, namely the study of the biogeography of forest timber species [24] and mammals in Angola [25]. Other recent examples of studies using the biological collections of IICT include the study of the botanical explorations of Cabo Verde [26] and GuineaBissau [27] and the conservation status assessment of the Cabo Verde native flora [28].

The study of traditional plant uses by African populations is another example of interdisciplinary research promoted in recent years. By combining ethnobotany and plant ecology methods, the study of botanical collections is instrumental for cataloguing plant properties and uses accumulated over generations. This traditional knowledge represents an important cultural heritage and conveys relevant information about the potential of tropical floras. In this regard, research developed in the IICT has made recently available comprehensive ethnobotanical datasets for different African countries, including Angola [29], Guinea-Bissau [30] and Mozambique [31]. Furthermore, several studies were published based on the unique collections housed in CIFC (e.g., coffee leaf rust pathogen collections) [32] or in the response of Coffea species to cold impact and acclimation [33], which have contributed collectively to raise the quality and impact of the IICT's excellence at all levels of research.

Other important outputs include contributions to heritage conservation, namely in liquid collections [34], cultural heritage biodeterioration issues [35-36], integrated pest management [37], air quality and risk assessment [38-39], and conservation management issues, and disaster planning [4041]. In the area of conservation, IICT gave priority to training and received students from different conservation schools, namely from the conservation and restoration department of NOVA University of Lisbon. IICT also provided opportunities for training, research, and networking, promoting capacity building in CPLP countries through the organization of courses and workshops, such as the international "Preventive Conservation Course" for archivists and librarians, promoted by the Arquivo Histórico de Moçambique/Universidade Eduardo Mondlane, with the support of the International Archives Council, in August 2014.

Other interdisciplinary studies worth mentioning targeted the ethnography and anthropology heritage and the archaeological collections involving, for example, Mozambique [42-43], Angola [44-46] and East Timor [4748]. Other relevant publications refer to studies in the field of oral history [49], institutional history and history of science [50-52].

The dynamic atmosphere experienced during these years contributed to disseminate previous and ongoing studies carried out by researchers from IICT and partners. At the same time, new digital content on tropical issues 
was produced and disseminated. A vivid idea of the work undertaken under the aegis of this initiative is given by the numbers achieved by the end of 2014: ca. 270,000 items catalogued and ca. 185,000 items encoded as records in different databases, of which ca. 177,000 were made available online through ACTD. The ACTD reached 905,477 views and 244,714 downloads, accessed by 206,083 different locations, in Europe, Africa, America and Asia, becoming a reference for international research on tropical issues. We have no numbers after the integration of IICT in the University of Lisbon in 2015, but ACTD is still the largest RNOD provider at national level.

Other relevant outcomes include 18 exhibitions organised during this period both in IICT and in CPLP countries. The already mentioned "Viagens e Missões Científicas nos Trópicos" explored the portuguese scientific agenda for the tropics, between the monarchy and the republic, as well as current research based on the Millennium Development Goals. This exhibition, presented in Calheta Palace between November 2010 and January 2012, deserves to be singled out due to the organization of more than 50 complementary workshops focusing on IICT collections and leading to the first "International Colloquium on Science in the Tropics". Another important achievement was the Memory of the World International Register of the Ndembo Archives (Angola), in 27 July 2011, proposed by IICT/AHU and the Angola National Archive to the UNESCO program Memory of the World. The IICT Heritage Week (i.e., Semana do Património), in 2007, was also a milestone, involving guide tours and an exhibition open to the general public, plus a seminar and a round table for the scientific community.

Briefly, the management of the IICT scientific and historic collections and resources, together with the study, treatment and digitisation efforts done more recently in the framework of these initiatives and different projects, have greatly contributed to improve the recognition of this heritage by the general public and the scientific community, mainly through the access to exhibitions and science dissemination and outreach events, the availability of the unique data in large public repositories and networks (e.g., GBIF, EUROPEANA and ACTD) and the publication of scientific papers and training initiatives.

\section{SWOT analyses}

The evaluation of IICT collections and heritage clearly indicates that without the 10 years (2005 to 2015) under the Portuguese Initiative, several collections would have remained under unsatisfactory curatorial conditions. Moreover, the integration in the University of Lisbon would have been considerably more difficult and uncertain. In conservation terms, the main weakness and threats were gradually overcome. The creation of a team and the establishment of a preservation policy enabled problem identification, grounded decision making and the provision of essential facilities for collections preservation, access and use. The creation of specific access tools enabled their greater visibility and increased their use.

The integration of IICT collections and heritage in the University of Lisbon has been greatly facilitated by this previous work. Moreover, their management by MUHNAC, a museum with a curatorial tradition, technical facilities and specialized human resources, is encouraging for the future of these collections. Table 1 summarises a SWOT analysis of the intervention on the collections. In terms of strengths, if we believe that the 2005 interdisciplinary body of researchers can, in part, be compensated by the specialised curatorial work of MUHNAC; on the other hand, the decrease of IICT collections as a cooperation tool for Portuguese-speaking countries is a weakness that can hardly be compensated by the general understanding of the collections as important research infrastructures, since these are both important valences of this heritage. The detachment of the IICT researchers (mainly integrated in FLUL and ISA and with new concerns and challenges to face) is another weakness

Table 1. SWOT analysis considering a comparison of the scientific collections conditions at the beginning of Portuguese Initiative and 10 years later, after IICT "extinction by fusion" and the incorporation of scientific collections at University of Lisbon.

\begin{tabular}{|c|c|c|}
\hline & First assessment $-2005 / 2006$ & Second Assessment-2015/2016 \\
\hline Strengths & $\begin{array}{l}\text { - Unique collections of high interest } \\
\text { - Interdisciplinary body of researchers with specialized } \\
\text { knowledge of CH\&C }\end{array}$ & $\begin{array}{l}\text { - Previous survey and conservation treatments given by IICT } \\
\text { team, allows to get a full picture of the situation of the CH\&C } \\
\text { - Some of the destination places at UL are expected to have better } \\
\text { and specialised curation conditions }\end{array}$ \\
\hline Weaknesses & $\begin{array}{l}\text { - Insufficient specialised human resources and technical } \\
\text { facilities } \\
\text { - Preservation policy in the organisation nonexistent }\end{array}$ & $\begin{array}{l}\text { - Connection between collections and former IICT researchers } \\
\text { disrupted } \\
\text { - The impact of CH\&C as a cooperation tool tends to decrease } \\
\text { within the new institutional environment }\end{array}$ \\
\hline Opportunities & $\begin{array}{l}\text { - Institutional renovation process going on and reinforcement } \\
\text { of the international network } \\
\text { - Reinforcement of interdisciplinary work and projects } \\
\text { application opportunities }\end{array}$ & $\begin{array}{l}\text { - FCT fellows integration at ULisboa as essential elements for } \\
\text { knowledge transfer } \\
\text { - Participation in the PRISC and PORBIOTA infrastructures }\end{array}$ \\
\hline Threats & $\begin{array}{l}\text { - Poor storage conditions and high deterioration rate of some } \\
\text { collections } \\
\text { - Some collections were disorganised and their scope was } \\
\text { partially unknown }\end{array}$ & $\begin{array}{l}\text { - Providing data and data management of ACTD and BD stopped } \\
\text { - Partial dispersion of collections }\end{array}$ \\
\hline
\end{tabular}


that can be compensated by the opportunity of integration of fellows involved in the treatment of the collections in these last years. But this opportunity if not reached may become a real threat, resulting in a decrease of the rates of collections treatment and accessibility, as well as the expected scientific outputs. At the same time, the ACTD is at risk of losing its online visibility since the collections digitisation process has slowed down. This is a great loss after the international attention it attracted.

\section{Final remarks}

The European Union development policy indicates external cooperation programmes for furthering research and development in the Tropics, notably in Africa, as one of its goals [53]. There is a need to join efforts and to invest in the organisation of international networks and innovative research projects to fill the numerous gaps in our knowledge of tropical regions, especially in Sub-Saharan Africa. This will ultimately increase our understanding of these regions and contribute to their development. Accordingly, ensuring access to data from tropical regions is fundamental to foster future cooperation policies and actions, namely in Portuguese-speaking countries, where Portugal can lead by making available its scientific and historical collections and establishing bilateral research programmes.

The development of successive initiatives - from the Inter ministerial Heritage Management and Valorisation Program, the Tropical Scientific Archive to the Furthering of Tropical Knowledge Program - enabled the IICT to develop great expertise in the curation of historical and scientific collections in Portugal, shaped by an integrated and multidisciplinary perspective, as well as different methodological approaches. This achievement was only possible thanks to the support of FCT, which has funded human resources since 2004. A multidisciplinary team has developed an action plan oriented towards management and conservation, from the initial systematic survey and identification, organisation, indexing and cataloguing, preservation and conservation, to the computerisation, digitisation and dissemination of the collections from various scientific units. Moreover, the action plan involved a strong investment in new infrastructures, namely computer processing, online access and preservation facilities.

This investment by IICT and funding partners, especially FCT, has resulted in an enrichment and greater visibility of the scientific and historic collections and heritage. Importantly for its national outlook, IICT was integrated into two national consortia: 1) PRISC (i.e., Portuguese Research Infrastructure of Scientific Collections); and 2) PORBIOTA (i.e., Portuguese E-Infrastructure for Information and Research on Biodiversity), both included in the Portuguese Roadmap for Strategic Research Infrastructures [54].

Since 2005 , the entire scientific heritage of IICT has been identified and referenced, including the recovering of lost paper inventories, the upload of new databases and the organization of a transversal repository. In 2008, the ACTD was launched and it quickly became a reference search tool for researchers interested in collections from the tropical region, with thousands of views and downloads from all over the world. The availability of information from IICT collections has strengthen their potential for interdisciplinary research, creating new challenges for the scientific community and contributing to science in the tropics. Furthermore, international collaboration with African institutions has settled local capacity building as one of the priorities of IICT's action. In this context, the involvement of researchers from Portuguese-speaking African countries has been privileged, a cooperation and training policy that the University of Lisbon should continue.

Finally, tropical research within the University of Lisbon, and its national and international status as a study centre of historical and scientific heritage, would greatly benefit from adequate and active curation and study of IICT collections, which rank among the largest in the world for Portuguesespeaking African countries.

\section{Acknowledgements}

The work was funded by Fundação para a Ciência e Tecnologia (FCT) through the projects: i) former projects PI, ACT and PST; ii) Photo-Impulse (PTDC/COM-OUT/29608/2017) / ICNOVA - Instituto de Comunicação da NOVA; iii) PRISC (Portuguese Research Infrastructure of Scientific Collections) and iv) Aga Khan Development Network (AKDN) and FCT under the project CVAgrobiodiversity/333111699. Also to the Units funding: i) UID/AGR/04129/2019 to Linking Landscape, Environment, Agriculture and Food (LEAF), UID/BIA/00329/2019 to Centre for Ecology, Evolution and Environmental Changes (cE3c), and ii) Associated Laboratory for Green Chemistry-LAQV which is financed by national funds from FCT/ MCTES (UID/QUI/50006/2019) and co-financed by the ERDF under the PT2020 Partnership Agreement (POCI-01-0145-FEDER-007265).

The authors are also grateful to all team members of the full program under the Portuguese Initiative. A special thanks is due to the former IICT President, Professor Jorge Braga de Macedo, for the constant support and commitment to the success of this initiative. We also thank the thoughtful comments of the invited editor Dr. Marta Lourenço (MUHNAC-UL) and the two reviewers, which greatly improved our paper. Finally we are grateful to Dr. João Farminhão (Herbarium and Library of African Botany, Université Libre de Bruxelles) for helpful discussions and assistance with English editing.

\section{REFERENCES}

1 'Decreto-lei n. ${ }^{\circ}$ 141/2015, de 31 de Julho', Diário da República Série I, 148 (2015), https://dre.pt/home/-/dre/69920316/details/ maximized (accessed 2018-08-22).

2 Oliver, R., The African Experience: Major Themes in African History from Earliest Times to the Present, 2nd ed., Westview Press, USA (2000).

3 Carrisso, L. W., Ocupação Científica das Colónias Portuguesas: O que Há Feito - O Que Há a Fazer. Conferencia, Edições da $1^{a}$ Exposição Colonial Portuguesa, Tipografia Leitão, Porto (1934).

4 Instituto de Investigação Científica Tropical, Da Comissão de 
Cartographia (1883) ao Instituto de Investigação Científica Tropical (1983): 100 Anos de História, IICT, Lisboa (1983).

5 Casanova, C., "The heritage of Tropical Research Institute, Lisbon: A case-study and a strategy', in Spaces and Collections in the History of Science, ed. M. Lourenço \& A. Lourenço, Museum of Science of the University of Lisbon, Lisboa (2009) 245-257.

6 Lobato, M., 'Da Comissão de Cartografia ao Instituto de Investigação Científica Tropical (1883-1983)', in Saber Tropical 125 Anos, ed. T. P. Albino, IICT, Lisboa (2008) 12-94.

7 'Decreto-lei 26180, de 7 de Janeiro', Diário do Governo n. ${ }^{\circ}$ 5/1936, Série I (1936), https://dre.pt/application/file/528736 (accessed 2018-08-22).

8 'Decreto-lei 35395, de 26 de Dezembro', Diário do Governo $n .^{\circ}$ 287/1945, Série I (1945), https://dre.pt/application/file/463544 (accessed 2018-08-22).

9 Castelo, C., 'Investigação científica e política colonial portuguesa: evolução e articulações 1936-1974', História, Ciências, Saúde - Manguinhos, 19 (2) (2012) 391-408, http://www.scielo.br/pdf/hcsm/v19n2/03.pdf (accessed 2018-08-15).

10 'Lei 2048, de 11 de Junho', Diário do Governo n. ${ }^{\circ} 117 / 1951,1^{\circ}$ Suplemento, Série I (1951), https://dre.pt/application/file/153817 (accessed 2018-08-22).

11 'Decreto-lei 38300, de 15 de Junho', Diário do Governo n. ${ }^{\circ}$ 121/1951, Série I (1951), https://dre.pt/application/file/583510 (accessed 2018-08-22).

12 'Decreto-lei 583/73, de 6 de Novembro', Diário do Governo n. ${ }^{\circ}$ 259/1973, Série I (1973), https://dre.pt/application/file/412554 (accessed 2018-08-22).

13 'Decreto-lei 532/79, de 31 de Dezembro', Diário da República n. ${ }^{\circ}$ 300/1979, $5^{\circ}$ Suplemento, Série I (1979), https://dre.pt/application/ file/231224 (accessed 2018-08-22).

14 'Avaliação dos laboratórios de estado 1977. Relatório da avaliação do Instituto de Investigação Científica Tropical', typewritten manuscript, Observatório das Ciências e das Tecnologias, Ministério da Ciência e da Tecnologia, Lisboa (1997).

15 'Decreto-lei 105/82, de 8 de Abril', Diário da República n. ${ }^{\circ}$ 82/1982, Série I (1982), https://dre.pt/application/file/607050 (accessed 2018-08-22).

16 'Decreto-lei 249/89, de 8 de Agosto', Diário da República $n .^{\circ}$ 181/1989, Série I (1989), https://dre.pt/application/file/619212 (accessed 2018-08-22).

17 'Decreto-lei n. ${ }^{\circ}$ 297/2003', Diário da República n. ${ }^{\circ}$ 270/2003, Série I-A (2003), https://dre.pt/application/conteudo/438042 (accessed 2018-08-22).

18 'Despacho Normativo 32/2005, de 24 de Junho', Diário da República $n^{\circ}$ 120/2005, Série I-B (2005), https://dre.pt/application/file/233994 (accessed 2018-08-22).

19 II Reunião Ministerial de Ciência e Tecnologia dos Países da Comunidade de Países de Língua Portuguesa, Rio de Janeiro, 5 de Dezembro de 2003, Declaração final, http://www.cnpq.br/ documents/10157/5b428902-66c4-49ea-875a-dbcbe33cc037 (accessed 2018-08-20).

20 Lopes, S., 'Entrevista [à] Dra. Conceição Casanova, Directora de Serviços de Apoio e Responsável pelo Programa Interministerial de Tratamento e Divulgação do Património do IICT, 11 de Janeiro de 2007', in 3 anos pela renovação do Instituto de Investigação Científica Tropical, Instituto de Investigação Científica Tropical, Lisboa (2007) 58-76.
21 Viagens e Missões Científicas nos Trópicos: 1883-2010, ed. A. C. Martins \& T. Albino, IICT, Lisboa (2010).

22 Access policy, http://www2.iict.pt/archive/doc/ ACCESSPolicyIICT-15Out2013.pdf (accessed 2018-09-10).

23 Loan process regulation, http://www2.iict.pt/archive/doc/ IICT_LoanProcessRegulation.pdf (accessed 2018-09-10).

24 Romeiras, M. M.; Figueira, R.; Duarte, M. C.; Beja, P.; Darbyshire I., 'Documenting biogeographical patterns of African timber species using herbarium records: a conservation perspective based on native trees from Angola', PlosONE 9 (7) (2014) 1-11, https://doi.org/10.1371/journal.pone.0103403.

25 Rodrigues, P.; Figueira, R.; Vaz Pinto, P.; Araújo, M. B.; Beja, P., 'A biogeographical regionalization of Angolan mammals', Mammal review, 45 (2) (2015) 103-116, https://doi.org/10.1111/mam.12036.

26 Romeiras, M. M.; Duarte, M. C.; Santos-Guerra, A.; Carine, M. A.; Francisco-Ortega, J., 'Botanical exploration of the Cape Verde Islands: from the pre-Linnaean records and collections to the late 18th Century accounts and expeditions', Taxon 63 (3) (2014) 625-640, http://dx.doi.org/10.12705/633.37.

27 Romeiras, M. M.; Duarte, M. C.; Francisco-Ortega, J.; Catarino, L.; Havik, P., 'Recovering plant data for GuineaBissau: implications for biodiversity knowledge of West Africa', Diversity 10 (4) (2018) 109, https://doi.org/10.3390/ d10040109.

28 Romeiras, M. M.; Catarino, S.; Gomes, I.; Fernandes, C.; Costa, J. C.; Caujapé-Castells, J.; Duarte, M. C., 'IUCN Red List assessment of the Cape Verde endemic flora: towards a global strategy for plant conservation in Macaronesia', Botanical Journal of the Linnean Society 180 (2016) 413-425, http://dx.doi. org/10.1111/boj.12370.

29 Catarino, S.; Duarte, M. C.; Costa, E.; Carrero, P. G.; Romeiras, M. M., 'Conservation and sustainable use of the medicinal Leguminosae plants from Angola', PeerJ 23(7:e6736) (2019) 1-29, https://doi.org/10.7717/peerj.6736.

30 Catarino, L.; Havik, P.; Romeiras, M. M., 'Medicinal plants of Guinea-Bissau: therapeutic applications, ethnic diversity and knowledge transfer', Journal of Ethnopharmacology 183 (2016) 71-94, http://dx.doi.org/10.1016/j.jep.2016.02.032.

31 Ribeiro, A.; Romeiras, M. M.; Tavares, J.; Faria, M. T., 'Ethnobotanical survey in Canhane village, district of Massingir, Mozambique: medicinal plants and traditional knowledge', Journal of Ethnobiology and Ethnomedicine 6 (2010) 33-47, http://dx.doi.org/10.1186/1746-4269-6-33.

32 Talhinhas, P.; Batista, D.; Diniz, I.; Vieira, A.; Silva, D. N.; Loureiro, A.; Tavares, S.; Pereira, A. P.; Azinheira, H. G.; Guerra-Guimarães, L.; Várzea, V.; Silva, M. D. C., 'The coffee leaf rust pathogen Hemileia vastatrix: one and a half centuries around the tropics', Molecular Plant Pathology 18 (8) (2017) 1039-1051, https://doi.org/10.1111/mpp.12512.

33 Ramalho, J. C.; DaMatta, F. M.; Rodrigues, A. P.: ScottiCampos; P., Pais, I.; Batista-Santos, P.; Partelli, F. L., Ribeiro, A., Leitão, A. E., 'Cold impact and acclimation response of Coffea spp. Plants', Theoretical and Experimental Plant Physiology 26 (1) (2014) 5-18, https://doi.org/10.1007/ s40626-014-0001-7.

34 Casanova, C.; Conde, S., 'O programa de 'Promoção do Saber Tropical' no Instituto de Investigação Científica Tropical: olhar para o passado com perspetivas de futuro', Conservar Património 18 (2) (2013) 7-20, http://dx.doi.org/10.14568/cp2013005. 
35 Sequeira, S.; Cabrita, E. J.; Macedo, M. F., 'Antifungals on paper conservation: An overview', International Biodeterioration \& Biodegradation 74 (2012) 67-86, https://doi.org/10.1016/j. ibiod.2012.07.011.

36 Sequeira, S.; Cabrita, E. J.; Macedo, M. F., 'Fungal Biodeterioration of Paper: How are paper and book conservators dealing with it? An international survey', Restaurator 35 (2) (2014) 181-199, https://doi.org/10.1515/ rest-2014-0005.

37 Moura, L.; Gonçalves, C.; Sequeira, S.; Casanova, C., 'Controlo integrado de pragas no Arquivo Histórico Ultramarino do Instituto de Investigação Científica Tropical', in A Prática da Conservação Preventiva. Homenagem a Luís Elias Casanovas. IX Jornadas da Arte e Ciência UCP. V Jornadas ARP, ed. E. Vieira, Universidade Católica Editora, Porto (2015) 263-274.

38 Pinheiro, A. C.; Macedo, M. F.; Jurado, V.; Saiz-Jimenez, C.; Viegas, C.; Brandão, J.; Rosado, L., 'Mould and yeast identification in archival settings: Preliminary results on the use of traditional methods and molecular biology options in Portuguese archives', International Biodeterioration 8 Biodegradation 65 (4) (2011), 619-627, http://dx.doi.org/10.1016/j. ibiod.2011.02.008.

39 Pinheiro, A. C.; Viegas, C.; Viegas, S.; Verissimo, C.; Brandao, J.; Macedo, M. F., 'Indoor air quality in Portuguese archives: A snapshot on exposure levels risk', Journal of Toxicology and Environmental Health, 75 (22-23) (2012) 1359-1370, http://dx.doi. org/10.1080/15287394.2012.721168.

40 Casanova, C.; Moura, L.; Canas, A., 'Conservação versus acesso: Mapeamento de colecções', in Encontro Arquivos da Administração Pública. Atas, ed. M. F. Rollo, M. Ribeiro, P. Meireles \& P. Penteado, Faculdade de Ciências e Tecnologia da UNL, Instituto de História Contemporânea, Fundação para a Ciência e Tecnologia, Arquivo de Ciência e Tecnologia, Lisboa (2016) 54-69, https://act.fct.pt/wp-content/uploads/2016/03/ Atas-EAAP-eBook-2016.pdf (accessed 2018-09-15).

41 Casanova, C., 'Mudança de paradigma na conservação e restauro após a catástrofe: o caso de estudo dos documentos gráficos', Conservar Património 25 (2017) 15-22, http://dx.doi.org/10.14568/cp2016034.

42 Roque, A.C., 'Sources for the history of the southern border of Mozambique: Preliminary results of a project on the archives of the Portuguese Commission of Cartography', Journal of Borderlands Studies, 25 (2) (2010) 77-93, https://doi.org/10.1080/ 08865655.2010 .9695763$.

43 Roque, A. C., 'Missão Antropológica de Moçambique (19361956): A fotografia como instrumento de trabalho e propaganda', in O Império da Visão. Fotografia no Contexto Colonial Português (1860-1960), ed. P. L. Vicente, Fundação para a Ciência e Tecnologia, Lisboa (2015) 107-116.

44 Coelho, A. G.; Pinto, I.; Casanova, C, 'The archeologic collection of IICT in the new millennium. A coleção arqueológica do IICT no novo milénio', Antrope 1 (2014) 6-23, http://www.cta.ipt.pt/download/AntropeDownload/ ANTROPE\%201/antrope-Metodologias-TrabalhoArqueologico.pdf (accessed 2018-08-01).

45 Coelho, A. G.; Mota, P. F., 'Capangombe - Santo António(355-11). Uma estação lítica do sudoeste de Angola', in Viagens e Missões Científicas nos Trópicos 1883-2010, Instituto de Investigação Científica Tropical, Lisboa (2010) 106-109.

46 Casanova, C.; Coelho, A. G.; Pinto, I., 'Georeferencing four decades of an archaeological collection of Angola: a project for the future. Georeferenciando quatro décadas de uma coleção arqueológica de Angola: um projeto para o futuro', Antrope 5 (2016) 70-84, http://www.cta.ipt.pt/download/ AntropeDownload/ANTROPE\%205/texto_5.pdf (accessed 2018-09-01).

47 Roque, A. C.; Marques, V. R. Ferrão, L., 'Missão Antropológica de Timor: materiais e documentação no Instituto de Investigação Científica Tropical', in Missões Científicas e Antropologia Colonial. Atas do Colóquio Timor, ed. V. R. Marques, A. C. Roque \& R. Roque, Instituto de Investigação Científica Tropical, Lisboa (2011) 1-13, http://www. historyanthropologytimor.org (accessed 2018-09-01).

48 Castelo, C., 'Ruy Cinatti, the French-Portuguese Mission and construct of East Timor as an ethnographic site', History and Anthropology, 28 (5) (2017) 630-652, https://doi.org/10.1080/0275 7206.2017.1280672.

49 Castelo, C., 'Não tem a classificação americana, não existe!': História oral, ciência do solo tropical e imperialismo(s)', História Unisinos 18 (1) (2014) 136-145, http://dx.doi.org/10.4013/ htu.2014.181.12.

50 Martins, A., 'A Arqueologia nas missões científicas: ad initium', in Viagens e Missões Científicas nos Trópicos 1883-2010, Instituto de Investigação Científica Tropical, Lisboa (2010) 99-105.

51 Castelo, C., 'Scientific research and Portuguese colonial policy: developments and articulations, 1936-1974', História, Ciências, Saúde - Manguinhos, 19 (2) (2012) 391-408, http:// dx.doi.org/10.1590/S0104-59702012000200003.

52 Conde, P.; Martins, A. C.; Senna-Martinez, J. C., 'Archaeological connections: Tracking and tracing international relations throughout Portuguese colonialism', in History of Archaeology: International Perspectives. Proceedings of the XVII UISPP World Congress, ed. G. Deley, M. DíazAndreu, F. Djindjian, V. M. Fernández, A. Guidiand \& M.-A. Kaeser, vol. 11, Archaeopress Publishing, Oxford (2016) 51-62, http://www.archaeopress.com/Public/displayProductDetail. asp?id=\%7B23DD8A56-39E0-4146-841D-AE6DBEF51726\%7D (accessed 2018-09-15).

53 Castillejo, C., 'The European Union Trust Fund for Africa: a glimpse of the future for EU development Cooperation' Discussion Paper 22, German Development Institute, Bonn (2016), https://www.die-di.de/uploads/media/DP__22.2016. neu.pdf (accessed 2019-03-30).

54 Fundação para a Ciência e Tecnologia, Portuguese Roadmap of Research Infra-structures 2014-2020, FCT, Lisboa (2014).

RECEIVED: 2018.9 .30

REVISED: 2019.3 .31

ACCEPTED: 2019.5.30

ONLINE: 2020.3 .4

\section{(c) (i) $\odot$}

This work is licensed under the Creative Commons.

Attribution-NonCommercial-NoDerivatives 4.0 International License.

To view a copy of this license, visit:

http://creativecommons.org/licenses/by-nc-nd/4.o/deed.en. 